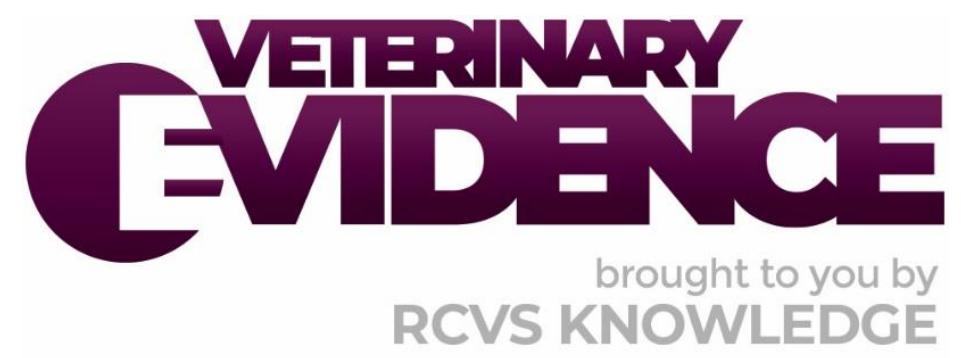

\title{
Does Grain Actually Predispose Our Cats to Gain Weight?
}

\author{
A Knowledge Summary by
}

Yaiza Gomez-Mejias LdaVet MANZCVS (Medicine of Cats) MRCVS ${ }^{1^{*}}$

\footnotetext{
${ }^{1}$ Meow MRCVS Ltd, 40 St Hildas Road, Stretford, Manchester, M16 9PQ, United Kingdom

*Corresponding Author (yaizagomezmejias@yahoo.co.uk)
}

ISSN: 2396-9776

Published: 15 May 2019

in: Vol 4, Issue 2

DOI: http://dx.doi.org/10.18849/ve.v4i2.201

Reviewed by: David Thomas (PhD, BSc) and Nicola Ackerman (BSc(Hons), RVN, CertSAN, CertVNECC, VTS(Nutr), A1 V1 MBVNA)

Next Review Date: 26 Apr 2020

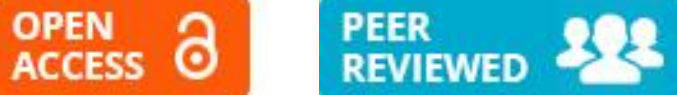




\section{KNOWLEDGE SUMMARY}

\section{PICO question}

In adult cats, does feeding grain free maintenance diet reduce the risk of obesity compared to feeding a maintenance diet containing grains?

\section{Clinical bottom line}

There is no evidence showing feeding grain free maintenance diet reduces the risk of obesity compared to feeding a maintenance diet containing grains.

\section{The evidence}

No published research evidence currently exists regarding the role of grain free diets in prevention of feline obesity.

During the literature search some primary research papers and non-systematic reviews were identified, where the role of carbohydrates in feline obesity was evaluated. Since grain is mainly used as a source of carbohydrates in pet food, this information has been taken into consideration for the appraisal, application and reflection. In some of them, specific types of grain are considered. However these studies do not specifically compare grain containing diets with grain free diets in order to evaluate the potential role of grain as a risk factor of obesity.

The majority of the papers did not mention any conflict of interest. However, research funds seem to be provided by pet food manufacturers in a great number of them.

\section{Appraisal, application and reflection}

Carbohydrates in the form of cereal grains or alternative sources make up from $20 \%$ to $50 \%$ of most extruded diets. Starch is what the largest portion of a whole grain is comprised of, and it is necessary to give structural integrity to the kibble. Despite being widely used in the pet food industry, cereal grains are poorly studied (1).

The carnivore nature of cats has led to speculations that high carbohydrate diets as dry food, could be detrimental for their health and lead to feline obesity. Obesity is a concern because it predisposes cats to insulin resistance, diabetes mellitus, lower urinary tract disease, osteoarthritis and skin problems.

The PICO question is based on the assumption that grain could be evaluated as an independent risk factor of feline obesity. However, risk factors for feline obesity seem to be multiple and interrelated.

On the other hand, different grains are sources of different types and amounts of carbohydrate (e.g. resistant starch, digestible starch, free glucose). Different sources of carbohydrate may differently influence weight gain (2).

In a recent study (3), the mean manufacturer reported carbohydrate content in the feline grain free diets was 
$25 \%$ lower than the reported carbohydrate content of the grain containing diets. However, there was considerable overlap between the groups and the individual diets' carbohydrate/nitrogen free extract content varied widely.

Assessing the evidence behind the influence of macronutrients on prevention of obesity is beyond the scope of this knowledge summary. However, given the frequent use of grain starch in extruded diets and the high percentage of starch contained in grain, reviews and studies retrieved on this search that focus on the effect of carbohydrates in weight gain, have been read and taken into consideration to write this appraisal.

Some experts $(4,5,6)$ state that, according to the research done on carbohydrates in feline diets, grain does not seem to contribute to feline obesity, compared to diets with an increased fat or protein content. But as this statement is based on experts' opinions, its grade of evidence is low (EBVM grade IV) (7). It seems to be the total energetic intake which affects the outcome.

From ten control trials retrieved during the search, that compare high carbohydrate with high fat or/and high protein diets, three show an increase in weight gain when cats are fed high carbohydrate diets, whilst seven show a greater weight gain in cats fed a high protein or high fat diet. However, only one of these ten papers includes wet food samples and most of them focus on management of overweight cats, rather than on risk of obesity. Conclusions about the influence of macronutrients in feline weight gain cannot be made based on this selection of papers since the literature search and the selection process were both focused on grain.

Given the high number of papers retrieved, many titles were excluded. As the latter usually do not show whether grain is considered in the text, exclusion and inclusion criteria were difficult to establish at this stage. Initially all titles related to feline diets were included. Then, those that did not suggest any association with weight gain or carbohydrates were excluded.

This initial exclusion criteria could have negatively affected the search results, as it may have allowed missing relevant content of some studies. However, by including "carbohydrates" amongst the search terms, we have avoided ignoring plenty of information that would have been omitted otherwise. Initially a more specific grain related search strategy was attempted but it was considered non-representative of the current scientific evidence regarding this PICO question.

The majority of the papers did not mention any conflict of interest. However, research funds seem to be provided by pet food manufacturers in a great majority of the papers. This possible bias may influence owners and veterinarian's perception of the evidence available. The current general concern amongst owners and veterinarian's about feline obesity would justify more independent research about the role of grain in weight gain. 


\begin{tabular}{|c|c|}
\hline & \\
\hline $\begin{array}{r}\text { Databases searched and dates } \\
\text { covered: }\end{array}$ & $\begin{array}{l}\text { CAB Abstracts on the OVID interface } 1973 \text { to } 2018 \text { Week } 15 \\
\text { PubMed 1947-2018 Week } 15 \\
\text { VetMed Resource 1919-2018 Week } 15\end{array}$ \\
\hline Search terms: & $\begin{array}{l}\text { CAB Abstracts } \\
\text { 1. cat or cats or feline or felines or queen or queens or felis or } \\
\text { felidae or exp cats/ or exp Felis/ or exp Felidae/ } \\
\text { 2. pet or pets or exp pets/ } \\
\text { 3. carbs or carbohydrates or grain* or cereal* or wheat or corn } \\
\text { or rice or exp grain/ } \\
\text { 4. diet or diets or food or feed or exp diet/ } \\
\text { 5. (1 or } 2 \text { ) and } 3 \text { and } 4 \\
\text { PubMed } \\
\text { 1. } 1 \text { cats or feline or felines or pet or pets } \\
\text { 2. diet or dietary or food or feed } \\
\text { 3. carbs or carbohydrates or grain-containing or grain or cereal } \\
\text { or wheat or corn or rice } \\
\text { VetMed Resource } \\
\text { 1. } 1 \text { cat or cats or pet or pets } \\
\text { 2. diets or diet or dietary food or feed or foods } \\
\text { 3. carbs or carbohydrates or grain-containing or grain or cereal } \\
\text { or wheat or corn or rice }\end{array}$ \\
\hline Dates searches performed: & 26 April 2018 \\
\hline
\end{tabular}

\section{Exclusion / Inclusion Criteria}

\begin{tabular}{|c|l|}
\hline Exclusion: & $\begin{array}{l}\text { Grain but no association with obesity } \\
\text { Carbohydrates considered, but not grain } \\
\text { Non-peer reviewed material }\end{array}$ \\
\hline Inclusion: & $\begin{array}{l}\text { Grain/carbohydrates in feline diets } \\
\text { Feline obesity, food intake, energy source, macronutrients } \\
\text { Primary research papers } \\
\text { Systematic reviews (SR) }\end{array}$ \\
\hline
\end{tabular}




\begin{tabular}{|c|c|c|c|c|c|c|c|c|}
\hline \multicolumn{9}{|c|}{ Search Outcome } \\
\hline Database & $\begin{array}{c}\text { Number of } \\
\text { results }\end{array}$ & $\begin{array}{l}\text { Excluded - } \\
\text { Duplicates }\end{array}$ & $\begin{array}{l}\text { Excluded - } \\
\text { title not } \\
\text { related to } \\
\text { PICO }\end{array}$ & $\begin{array}{l}\text { Excluded - } \\
\text { content not } \\
\text { related to } \\
\text { PICO }\end{array}$ & $\begin{array}{l}\text { Excluded - not } \\
\text { primary } \\
\text { research or } \\
\text { systematic } \\
\text { reviews }\end{array}$ & $\begin{array}{c}\text { Excluded - unspecific } \\
\text { source of } \\
\text { carbohydrates }\end{array}$ & $\begin{array}{c}\text { Excluded - a number } \\
\text { of types of grain used } \\
\text { as source of } \\
\text { carbohydrates } \\
\text { considered but not } \\
\text { compared to grain } \\
\text { free diets }\end{array}$ & $\begin{array}{l}\text { Total } \\
\text { relevant } \\
\text { papers }\end{array}$ \\
\hline PubMed & 732 & 0 & 713 & 8 & 3 & 3 & 5 & 0 \\
\hline $\begin{array}{l}\text { VetMed } \\
\text { Resource }\end{array}$ & 522 & 63 & 417 & 26 & 12 & 2 & 2 & 0 \\
\hline CAB Abstracts & 991 & 410 & 400 & 176 & 5 & 0 & 0 & 0 \\
\hline \multicolumn{8}{|c|}{ Total relevant papers when duplicates removed } & 0 \\
\hline
\end{tabular}


The author declares no conflict of interest.

I would like to thank Clare Boulton for assistance and patience in running searches.

\section{REFERENCES}

1. Beloshapka AN, Buff PR, Fahey Jr GC and Swanson KS. Compositional Analysis of Whole Grains, Processed Grains, Grain Co-Products, and Other Carbohydrate Sources with Applicability to Pet Animal Nutrition. Foods 2016, 5, 23 DOI: https://doi.org/10.3390/foods5020023

2. Appleton, D.; Rand, J.; Priest, J.; Sunvold, G.; Vickers, J. Dietary carbohydrate source affects glucose concentrations, insulin secretion, and food intake in overweight cats. Nutrition Research. 2004, 24(6), 447-467. DOI: https://doi.org/10.1016/i.nutres.2004.03.002

3. Prantil, L.R., Heinze, C.R. \& Freeman, L.M. Comparison of carbohydrate content between graincontaining and grain-free dry cat diets and between reported and calculated carbohydrate values. Journal of Feline Medicine and Surgery 2018, Vol. 20(4) 349-355. DOI: https://doi.org/10.1177/1098612X17710842

4. Laflamme, D., Izquierdo, O., Eirmann, L., \& Binder, S. Myths and Misperceptions About Ingredients Used in Commercial Pet Foods. Veterinary Clinics of North America - Small Animal Practice, 44(4), (2014), 689-698. DOI: https://doi.org/10.1016/i.cvsm.2014.03.002

5. Villaverde, C. \& Fascetti A.J. Macronutrients in Feline Health. Veterinary Clinics of North AmericaSmall Animal Practice, 44(4), (2014), 699-717. DOI: https://doi.org/10.1016/i.cvsm.2014.03.007

6. Verbrugghe, A. \& Hesta, M. Cats and Carbohydrates: The Carnivore Fantasy? Veterinary Science. 2017, 4(4), 55. DOI: https://doi.org/10.3390/vetsci4040055

7. EBVM Toolkit 3 - Introduction to "Levels of evidence" and study design. Retrieved from https://knowledge.rcvs.org.uk/document-library/ebvm-toolkit-3-introduction-to-levels-of-evidenceand-study/ May 13, 2019 


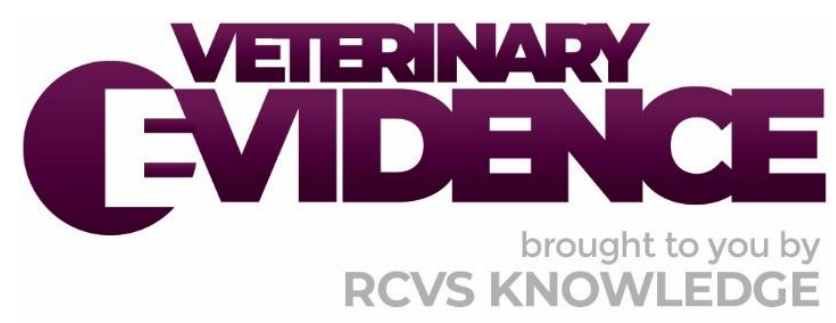

\section{Intellectual Property Rights}

Authors of Knowledge Summaries submitted to RCVS Knowledge for publication will retain copyright in their work, and will be required to grant RCVS Knowledge a non-exclusive license of the rights of copyright in the materials including but not limited to the right to publish, re-

publish, transmit, sell, distribute and otherwise use the materials in all languages and all media throughout the world, and to license or permit others to do so.

\section{Disclaimer}

Knowledge Summaries are a peer-reviewed article type which aims to answer a clinical question based on the best available current evidence. It does not override the responsibility

of the practitioner. Informed decisions should be made by considering such factors as individual clinical expertise and judgement along with patient's circumstances and owners' values. Knowledge Summaries are a resource to help inform and any opinions expressed within the Knowledge Summaries are the author's own and do not necessarily reflect the view of the RCVS Knowledge. Authors are responsible for the accuracy of the content. While the

Editor and Publisher believe that all content herein are in accord with current recommendations and practice at the time of publication, they accept no legal responsibility

for any errors or omissions, and make no warranty, express or implied, with respect to material contained within.

For further information please refer to our Terms of Use.

RCVS Knowledge is the independent charity associated with the Royal College of Veterinary Surgeons (RCVS). Our ambition is to become a global intermediary for evidence based veterinary knowledge by providing access to information that is of immediate value to practicing veterinary professionals and directly contributes to evidence based clinical decision-making.

https://www.veterinaryevidence.org/

RCVS Knowledge is a registered Charity No. 230886.

Registered as a Company limited by guarantee in England and Wales No. 598443.

Registered Office: Belgravia House, 62-64 Horseferry Road, London SW1P 2AF

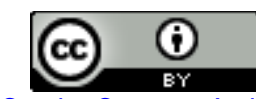

This work is licensed under a Creative Commons Attribution 4.0 International License 